\title{
Promosi Karya Seni Rupa Berdasar Kategori
}

\author{
Teddy K Wirakusumah \\ Prodi Manajemen Komunikasi Fakultas Ilmu Komunikasi Universitas Padjadjaran
}

\begin{abstract}
ABSTRAK
Jenis-jenis karya yang dihasilkan oleh perupa informan terkait bidang seni rupa ternyatasangat beragam. Masing-masing membutuhkan cara promosi yang berbeda. Penelitian dengan judul Promosi Karya Seni Rupa Berdasar Kategori bermaksud untuk memahami bagaimana perupa mempromosikan karyanya berdasarkan jenis karya yang dihasilkan.

Metode penelitian yang digunakan adalah Metode Kualitatif dengan tradisi Fenomenologi. Subjek penelitian adalah Perupa di Kota Bandung yang dipilih secara purposif sebanyak 13 orang.

Pengumpulan data dilakukan dengan metode wawancara mendalam. Sejumlah pertanyaan yang diajukan dibuat dalam bentuk daftar pertanyaan terbuka dan berlangsung dalam suasana informal. Hasil penelitian mengungkapkan: Karya Pribadi dan Karya Kompetisi dipromosikansecara personal sebelum diperkenalkan lewat pameran. Karya tersebut baru dipromosikan di media sosial setelah melalui sejumlah pameran. Sebagian besar jenis karya lainnya dipromosikan di media sosial begitu karya diselesaikan. Karya-karya pesanan jenis khusus memiliki potensi dikembangkan lewat promosi yang disesuaikan dengan target sasaran.
\end{abstract}

Kata-kata Kunci: perupa, promosi, seni rupa, jenis karya

\section{Artwork Product Promotion based on Category}

\begin{abstract}
The types of artworks produced by informant artists related to the field of fine art turnedout to be very diverse. Each requires a different type of promotion. Research with the title of Promotion of Fine Art by Category aims to understand how artists promote their artwork basedon the type of artwork produced.

The research method used is a Qualitative Method with the Phenomenology tradition. The research subjects were artists in Bandung who were purposively selected as many as 13people. Data collection is done by in-depth interview method. A number of questions were asked in the form of an open list of questions and took place in an informal setting.

The results of the study revealed: Private ArtWork and Competition Artwork were personally promoted before being introduced through the exhibition. The artwork was only promoted on social media after going through a number of exhibitions. Most other types of artwork are promoted on social media once the work is completed. Special types of orderartworks have the potential to be developed through promotions tailored to the target audience.
\end{abstract}

Keywords: artist, promotion, fine art, type of artwork

Korespondensi: Dr. Teddy K Wirakusumah, Drs., M.I.Kom. Universitas Padjadjaran. Jln. Raya

Bandung-Sumedang Km.21 Jatinangor. Email: teddy. k.wirakusumah@unpad.ac.id

ISSN: 2548-3242 (cetak), eISSN: 2549-0079 Website: http://jurnal.unpad.ac.id/manajemen-komunikasi 


\section{PENDAHULUAN}

Karya senirupa bukanlah benda yang menjadi kebutuhan primer. Bahkan ketika seseorang memiliki kemampuan untuk memenuhi kebutuhan primernya, belum tentu karya seni menjadi kebutuhan sekunder. Kebutuhan sekunder setiap orang berbeda-beda. Kebutuhan ini dipengaruhi oleh banyak faktor, seperti, gaya hidup, kepercayaan, lingkungan, tradisi, dan lain sebagainya. Menyadari hal tersebut, ketika seseorang memilih seniman/perupa menjadi profesi tunggal, ia harus yakin bukan saja mampu menghasilkan karya yang memiliki potensi ekonomi. namun berikut pengetahuan kepada siapa, kapan, dimana, dan bagaimana karya ditawarkan. Bagi perupa yang telah memiliki nama besar, populer dengan kualitas karya yang diapresiasi positif oleh publik mungkin tidak memiliki hambatan berarti. Proses perjalanan karyanya hingga sudah memiliki pola tertentu yang mereka kenali. Pelanggan ada, penggemar punya, tawaran kerjasama dengan berbagai pihak pun sangat terbuka. Namun bagi perupa yang masih dalam tahap rintisan dan tahap perkembangan, pilihan yang harus ditempuh tersebut tidaklah mudah.

Menyimak proses perjalanan karya yang dilalui para perupa dalam meraih sukses menarik diteliti. Walaupun masingmasing perupa berupaya untuk dikenal dan memiliki spesialisasi berkarya tertentu ternyata dalam prosesnya menghasilkan beragam jenis karya dan memiliki kemampuan untuk mengerjakan pekerjaan di luar spesialisasinya. Masing-masing ragam dari berbagai jenis karya yang dihasilkan memiliki potensi sebagai bahan promosi untuk meningkatkan aktualisasi diri perupa berikut karyanya secara keseluruhan. Namun, masing-masing kategori membutuhkan tindakan manajemen promosi spesisik.

\section{METODE PENELITIAN}

Penelitian ini dilakukan dengan pendekatan fenomenologi Tradisi studi fenomenologi menurut Creswel adalah:

"Where as a biography reports the life of a single individual, a phenomenological study describes the meaning of the live experiences for several individuals about a concept or the phenomenon" (Creswell, 1998:51).

Subjek dipilih secara purposif berdasarkan aktivitas dan kesediaan mereka untuk mengeksplorasi dan mengartikulasikan pengalaman mereka secara sadar. Oleh karena itu, dipilih informan, yaitu para perupa yang mampu mengartikulasikan pengalaman dan pandangannya tentang sesuatu yang dipertanyakan.

Pengumpulan data dilakukan dengan melakukan wawancara mendalam terhadap 13 perupa. Wawancara yang peneliti lakukan 
merupakan wawancara mendalam, bersifat informal dan tidak terstruktur.

Analisis data fenomenologis berlangsung melalui metedologi reduksi, analisis statemen tertentu dan tema, serta mencari makna-makna yang lain. Peneliti juga mengesampinghan praduga, bracketing dari pengalamannya, dan bergantung pada intuisi, imajinasi dan struktur universal untuk mendapatkan gambaran dari pengalaman

Oleh karena data penelitian ini berupa data kualitatif maka terdapat tiga alur kegiatan yang dilakukan secara bersamaan, yaitu: 1) Reduksi data 2) Penyajian data 3) Penarikan kesimpulan atau verifikasi

Keabsahan data dapat dilihat dari kemampuan menilai data dari aspek validitas dan reliabilitas. Validitas dalam penelitian kualittatif sering disebut dengan kredibilitas. Untuk menguji kredibilitas data penelitian dapat dilakukan dengan triangulasi. Triangulasi yang akan dilakukan adalah triangulasi sumber. Triangulasi sumber berarti membandingkan dan mengecek balik derajat kepercayaan suatu informasi yang diperoleh melalui waktu dan alat berbeda dalam metode kualitatif (Patton 1987:331 dalam Moleong, 2007: 178)

\section{HASIL DAN PEMBAHASAN}

Masing-masing perupa informan sekalipun dikenal memiliki spesialisasi berkarya tertentu ternyata menghasilkan beragam jenis karya dan kemampuan untuk mengerjakan pekerjaan di luar spesialisasinya. Motif pembuatan dan perlakuan pasca berkarya pada masingmasing kategori jenis karya yang dihasilkan bermacam-macam. Selama kegiatan pengumpulan data dan penulisan laporan penelitian, jenis-jenis karya yang dihasilkan oleh perupa informan terkait bidang seni rupa ternyata sangat beragam. Untuk mempermudah penjelasan jenis karya yang beragam dikategorikan menjadi 2 jenis yaitu Karya Independen dan Karya Pesanan.

\section{A. Karya Independen}

Sebagian besar perupa informan selalu menyisihkan waktu untuk membuat karya independen. Yang dimaksud dengan karya independen adalah karya yang merupakan ekspresi bebas berdasarkan pada keinginan pribadi perupa sendiri. Karya seperti ini dipastikan bukan pesanan pihak lain. Karya independen dapat dibedakan sebagai berikut:

\section{Karya Pribadi}

Karya pribadi biasanya terkait dengan spesialisasi yang selama ini dikenali dan dihayati. Boleh jadi hasil perenungan lama yang sarat pertimbangan, baik secara konseptual, teknik maupun keberminatan pasar tapi tidak "pasaran”. Karya serupa ini biasanya dikerjakan penuh kesungguhan.

Sebagian besar perupa lebih suka membuat karya pribadi. Tidak ada beban dan tidak diburu waktu. Namun tuntutan untuk 
keamanan menafkahi keluarga, para perupa juga mengerjakan pekerjaan pesanan yang memiliki tingkat kepastian untuk terjual.

Karya pribadi umumnya ditujukan untuk menanggapi suatu tawaran pameran atau untuk menambah koleksi studio. Jika karya pribadi sudah usai, karya baru serupa ini biasanya hanya diperkenalkan secara personal pada pelanggan dan kolektor, Targetnya, agar terkesan spesial, mendapat respon dan berharap transaksi dapat berlangsung. Karya baru seperti ini juga biasanya diperkenalkan pada kurator, dan pemilik galeri dengan target dapat diikutsertakan dalam jadwal pameran jika ada. Tak jarang, upaya promosi secara personal ini mencapai target sesuai harapan.

Walaupun semua informan perupa memiliki akun media sosial, cenderung menahan diri atau tidak mengunggah karya pribadi yang baru diselesaikan mereka ke media sosial sebelum karya tersebut terjual atau dipresentasikan dalam sejumlah pameran. Mereka lebih suka, karya serupa itu melengkapi koleksi yang sudah ada di studio. Mereka berharap saat ada yang datang berkunjung ke studio, selalu melihat karya yang belum pernah mereka lihat.

Adakalanya karya pribadi dipromosikan di media sosial, namun umumnya saat karya masih dalam proses atau belum selesai. Daripada sekadar update status yang hanya menghasilkan like dan comment, para perupa informan lebih menyukai mengunggah karya sekalipun karya masih dalam proses. Mengunggah karya seperti umpan saat memancing ikan, kerapkali mendatangkan pesanan. Besar kemungkinan, ada orang-orang yang sejak lama bermaksud memesan karya, dan ketika karya diunggah ia merasa diingatkan.

Karya pribadi yang sudah diselesaikan secara utuh mungkin saja diunggah di media sosial, jika karya tersebut merupakan karya lama. Seluruh informan sudah banyak berkarya jauh sebelum media sosial tersedia seperti sekarang. Perupa memahami bahwa tidak semua pembaca media sosial mereka pernah mengenal karya yang pernah dihasilkannya Terlebih karya di masa lalu yang boleh jadi telah berganti pemilik. Berdasarkan dokumentasi yang dimiliki ia mencoba memperkenalkan karya pribadi yang pernah dibuatnya, walau merupakan karya lampau. Terkadang karya pribadi yang pernah diunggah lama sebelumnya, diulang diunggah lagi.

\section{Karya Kompetisi}

Sebagian perupa menganggap karya independen tidak selalu bermakna karya ekspresi yang benar-benar bebas. Mereka menganggap bisa saja karya independen ini terkait dengan tema tertentu pada suatu event kompetisi. Sebagaimana diketahui, terdapat beberapa instansi yang memiliki kegiatan rutin (setiap tahun atau 2 tahun sekali) memberikan penghargaan terhadap karya 
senirupa terbaik dengan hadiah besar. sebagai pesan promosi untuk mengingatkan. Penghargaan diberikan kepada karya yang Bahkan, untuk sebagian informan perupa, didaftarkan dan biasanya kompetisi sekalipun kompetisi sudah usai karya serupa menawarkan tema tertentu. Temanya itu beralih posisi diperlakukan seperti karya biasanya sangat luas, sehingga terbuka pribadi dan perlakuan promosinya serupa.

penafsiran yang sangat beragam. Itu sebabnya sebagian perupa mengganggap berkarya untuk kompetisi serupa ini masih dalam kategori berkarya independen. Yang penting karya yang dihasilkan merupakan perenungan pribadi, tanpa campur tangan siapa pun.

Seperti halnya karya pribadi, karya kompetisi biasanya dikerjakan dengan penuh kesungguhan sejak mulai merancang gagasan. Berbagai rujukan digunakan, baik berupa naskah maupun rujukan visual, agar konsep yang mendasarinya terbangun kokoh. Demikian pula terkait aspek teknik. Penggunaan media, bahan, dan alat diupayakan terpilih, agar dapat mendukung gagasan seutuhnya dan menghasilkan karya akhir sebaik-baiknya. Jika karya berbentuk lukisan, maka pemilihan kanvas, cat dan penggunaan kwas menjadi utama. Itu sebabnya tak jarang karya yang diproduksi seperti ini kemudian menjadi karya andalan.

Perlakuan terhadap karya kompetisi mirip dengan perlakuan terhadap karya pribadi. Mereka cenderung menahan diri atau tidak mengunggah karya pribadi mereka ke media sosial, jika belum ada pengumuman hasil, Kalaupun ada yang diunggah, biasanya saat karya dalam proses dan lebih berperan

\section{Karya Insidental}

Jika karya pribadi dan karya kompetitif dibuat dengan penuh pertimbangan kesungguhan, dan menggunakan waktu yang sengaja disisihkan, karya insidental lebih bersifat spontan, ekspresi kehendak yang tiba-tiba, atau bisa juga karena iseng, untuk membunuh waktu atau untuk mempermahir cara yang diperoleh melalui workshop. Pengerjaannya bisa kapan saja dan dimana saja. Umumnya dikerjakan saat memiliki waktu luang dan biasanya berupa sketsa.

Berbeda dengan karya pribadi dan karya kompetitif, karya-karya insidental biasanya selalu diunggah ke media sosial begitu karya diselesaikan. Bagi sebagian besar perupa, sejak muncul kesadaran kehadiran media sosial merupakan alternatif untuk aktifitas promosi, mereka memilih menjadi pengguna aktif. Update status di media sosial bagi sebagian besar Perupa rupanya menjadi hal penting. Update status sambil mengunggah karya dinggap lebih utama. Berdasarkan pengalaman yang dialami, unggah karya seperti umpan untuk memancing rejeki. Itu sebabnya kontinuitas mengunggah karya senantiasa diupayakan. Sehubungan dengan hal tersebut, karya- 
karya yang dihasilkan insidental, sekadar iseng, sekadar untuk membunuh waktu menjadi alternatif cukup bermanfaat untuk menjaga kontinuitas, karena tak memakan waktu dan pikiran.

Untuk memaksimalkan nilai promotif, sebagian perupa informan memilih untuk cerdik memilih obyek atau moment saat membuat karya insidental. Sketsa yang dibuat saat pejabat dilantik, saat kandidat sidang promosi doktor, mempelai yang tengah menikah, orang terkenal saat sakit/meninggal dunia, peringatan yang melibatkan banyak orang, peristiwa yang sedang trend di media sosial (bencana, advokasi, dll) lazim mengundang banyak perhatian dan mudah mendapat simpati. Jika moment tersedia dan hasrat berkarya ada, mengabadikan hal tersebut dalam bentuk karya insidental merupakan pilihan menarik dan strategis.

Sekalipun tanpa perencanaan dan terkesan seadanya tidak mustahil karya seperti ini diminati dan bernilai ekonomis. Beberapa perupa informan mendapatkan pengalaman berulang bahwa karya insidental seperti ini mendapatkan penawaran di media sosial. Ada yang menambahkan permintaan khusus, seperti minta dipindah ke kanvas, ada yang memintanya menjadi elemen illusrasi, dsb. Kalaupun tidak berkahir dengan penawarnan karya-karya insidental tetap berguna. Bahkan terkadang karya-karya insidental di kemudian hari bisa saja menjadi bahan untuk dikembangkan sebagai karya pribadi dan karya kompetitif atau menjadi materi pelengkap saat Pameran Tunggal.

\section{Karya Uji Coba}

Perupa informan sekalipun telah memiliki reputasi yang sepenuhnya dihargai berdasarkan keahliannya ternyata merupakan orang-orang yang terbuka untuk mencoba berkarya atau mendapatkan pengetahuan baru. Oleh sebab itu tak heran jika menjumpai perupa informan bereksperimen dengan teknik baru, atau mengikuti workshop tentang sesuatu yang kurang atau belum pernah dikuasainya.

Jika karya yang dihasilkan ternyata cukup pantas untuk diperkenalkan pada kpublik, proses dan karya akhir dapat menjadi bahan promosi berguna untuk memperluas pengenalan terhadap kemampuan yang dimiliki perupa yang bersangkutan.

\section{Karya Berdasarkan Tantangan}

Karya berdasarkan tantangan merupakan tren baru yang hanya ada di masa kini, ketika media sosial seperti sekarang ini. Karya berdasarkan tantangan banyak ragamnya. Beberapa aktivitas berkarya yang didasarkan tantangan bahkan memiliki popularitas tertentu. Popularitasnya tidak sekadar lokal dan nasional tapi juga berskala global, misal \#INKTOBER. 
Inktober adalah proyek tantangan bagi perupa di seluruh dunia untuk membuat gambar menggunakan alat tradisional yang berbahan dasar tinta selama bulan Oktober. Jadi, selama bulan Oktober, perupa harus menghasilkan satu gambar setiap harinya secara konsisten. Karya tersebut kemudian diunggah ke media sosial Instagram dengan hastag \#inktober.

Inktober sendiri dicetuskan oleh Jake Parker pada tahun 2009, sebagai bentuk kampanye agar para perupa dapat meningkatkan kemampuan mereka melukis menggunakan tinta dan membangun kebiasaan positif dalam menggambar. Ternyata Inktober ini disambut baik oleh semua orang di dunia, termasuk di Indonesia. Pada tahun 2017 lalu selama bulan oktober gambar yang diunggah dengan hashtag \#inktober2017 berjumlah 3.189.023 buah.

Dari sisi promosi, keikutsertan membuat karya berdasarkan tantangan merupakan promosi yang menarik. Jika memperhatikan jumlah keterlibatan yang berpartisipasi dan banyak perusahaan yang turut terlibat ambil bagian sebagai sponsor menunjukkan karya berdasarkan tantangan ini sangat potensial sebagai ajang promosi. Mengingat keberlangsungannya rutin tahunan, sebenarnya karya bisa dipersiapkan jauh-jauh hari sebelumnya sehingga proses dan karya dapat terdokumentasikan dengan baik dan menjadi bahan promosi yang optimal.

\section{Karya dalam Event}

Para perupa informan telah memilih senirupa menjadi bagian hidup yang penting. Sebagian besar Perupa Informan bahkan memilih perupa sebagai profesi utama. Menggambar bagi sebagian besar perupa menjadi bagian dalam aktivitas kehidupan. Baik dilakukan sendirian seperti saat membuat karya insidental maupun bersamasama. Saling mengajak menggambar bersama bukanlah suatu asing. Bisa berlangsung spontan atau terformalkan dalam sebuah undangan acara/event. Menggambar bersama yang terformalkan dalam suatu event beragam bentuknya. Ada yang merupakan Sisipan Acara Pameran, Event Menggambar Insidental, dan Event Menggambar Rutin.

Untuk menarik perhatian pengunjung, pameran seni rupa saat ini biasanya tidak hanya sekadar memajang karya, tetapi menyisipkan dengan berbagai acara. Salah satu acara yang sering disisipkan untuk menarik perhatian pengunjung adalah acara Menggambar Bersama, baik yang dilakukan peserta pameran maupun mengajak pihak lain.

Sedangkan Acara menggambar insidental adalah acara menggambar bersama yang dikelola oleh sebuah komunitas dalam rangka memperingati sesuatu. Biasanya hanya berlangsung satu sesi dengan tema yang ditentukan. 
Sedangkan event menggambar rutin berlangsung secara berkesinambungan, terjadwal tetap dan konsisten. Komunitas yang menggelar acara menggambar bersama secara rutin ini misalnya Bandung Sketchwalk (BSW). Acara menggambar bersama yang diadakan BSW berlangsung hanya 1 kali sebulan. Setiap Hari Minggu pertama tiap bulan.

Dari sisi promosi mengunggah aktivitas berkarya bersama memiliki nilai tambah berharga, karena besar kemungkinan peserta lainnya pun melakukan hal serupa. Ditambah dengan kebiasaan saling menandai teman maka jangkauan (reach) bertambah luas.

\section{B. Karya Pesanan}

Bagi Perupa informan yang memiliki pekerjaan tetap selain menjadi perupa, menggunakan waktu di luar pekerjaan utama untuk berkarya independen tidak terlalu menjadi masalah. Namun bagi yang memilih menjadi perupa sebagai profesi utama, sebagian besar perupa informan lebih mengandalkan hidup dari berkarya berdasarkan pesanan. Penjualan karya independen di studio pribadi, atau yang dititipjualkan di galeri atau yang diikutsertakan di pameran sangat bergantung banyak hal untuk dapat terjual. Untuk mensiasati kebutuhan keluarga sehari-hari para perupa menerima berbagai karya pesanan. Walaupun pernah dikatakan bahwa karya independen dibuat dengan penuh kesungguhan, tidak berarti bahwa karya pesanan dibuat alakadarnya. Karya pesanan tetap dikerjakan secara serius, yang berbeda, karya pesanan biasanya dibatasi waktu,.

Dalam banyak kejadian para perupa informan seluruhnya menerima pekerjaan pesanan. Walaupun masing-masing memiliki spesialisasi yang dikenali, pesan yang ditawarkan ternyata sangat beragam dan tidak selalu selaras dengan spesialisasi yang dikenal. Ragam pesanan selama penelitian berlangsung terhadap para informan secara garis besar dapat dibagi 2 menjadi Pesanan Karya Mandiri dan Pesanan Karya Bersama

\section{Pesanan Karya Mandiri}

Pesan Karya Mandiri adalah pesanan langsung pada perupa informan untuk dikerjakan secara mandiri tanpa bantuan pihak lain. Pesanan seperti ini umumnya terkait keahlian yang dikenal. Permintaan pesanan seperti seringkali bearasal dari orang yang dikenal, pelanggan, galeri, kolektor atau tidak tertutup kemungkinan dari orang yang asing namun mendapat rekomendasi dari seseorang.

\section{a. Pesanan Lukisan Wajah}

Sebagian besar perupa informan dikenal sebagai pelukis, itu sebabnya sebagian besar karya pesanan adalah karya lukis. Boleh jadi karena sebagian besar perupa adalah pelukis realis, permintaan 
lukisan lebih ke arah figuratif. Pesanan lukisan yang paling banyak diminta adalah permintaan pesanan lukisan diri (hanya wajah atau sebagian besar/seluruh tubuh). Pemesan bisa perorangan atau instansi. Subyek dalam lukisan bisa si pemesan sendiri atau orang lain (biasanya untuk hadiah). Media dan teknik yang digunakan tergantung keinginan pemesan. Ada yang di atas kertas dengan menggunakan pensil, charcoal, pastel, atau cat air atau di atas kanvas dengan menggunakan cat minyak atau acrilic.

Tahapan pembuatan pesanan lukisan diri bisa sangat sederhana tapi bisa cukup kompleks. Berawal dari transaksi pesanan, setiap perupa informan ternyata mengawali tahapan awal bisa berbeda satu dengan lainnya. Ada yang lebih menyukai menggambar/langsung di tempat, ada yang lebih suka menundanya dengan berbatas waktu. Pemesan difoto lalu dikerjakan di studio. Bagi yang lebih menyukai menggambar langsung, ada yang memilih menggambar di tengah kerumunan, ada yang lebih asyik menggambar di studio. Ada juga yang lebih menyukai, membuat sketsa di tempat, difoto, dan dilanjutkan di studio. Selain itu ada pula - biasanya pesanan lewat media sosial - menggambarnya berdasarkan foto yang dikirim. Untuk pilihan yang terakhir, para perupa biasanya lebih berhatihati (terutama jika wajah yang dipesan tidak dikenal) dengan meminta berbagai alternatif foto, karena adakalanya foto bisa berbeda wajah asli. Pilihan tersebut diambil untuk memperkecil kemungkinan komplain.

Apapun pilihannya, masing-masing memiliki potensi sebagai bahan promosi yang jika dikelola dengan baik dapat memberikan manfaat positif. Idealnya selama saat proses berlangsung dan karya yang dihasilkan didokumentasikan (baik berupa foto ataupun audiovisual). Dokumentasi proses dan lukisan wajah merupakan bahan menarik untuk mempromosikan kemampuan perupa di media sosial. Terlebih jika mempertimbangkan anggapan umum bahwa kemampuan menghasilkan kemiripan wajah dalam gambar/lukisan adalah kemampuan unik yang menandai seorang seniman pantas mendapat sebutan sebagai Perupa.

Pilihan menggambar langsung di tempat apalagi di tengah kerumunan, hasilnya bisa tidak maksimal tapi besar kemungkinan orang mudah maklum. Yang pasti, hasil transaksi dapat dimiliki saat itu juga. Dari sisi promosi pilihan ini memiliki nilai tambah sebagai ajang pembuktian absah bahwa perupa yang bersangkutan memang memiliki kemampuan seperti yang dipertontonkan. Nilai tambah lainnya, adakalanya selain dari pihak perupa, promosi tambahan diperoleh dari penonton yang secara sukarela membuat dokumentasi dan membagikannya di media sosial miliknya. Bahkan terkadang membagikannya dalam 
bentuk siaran langsung. Nilai tambah seperti ini merupakan berkah sehingga dapat memperluas jangkauan (reach) ke masyarakat luas.

Pilihan menggambar langsung di studio, pilihan waktu bisa diatur lebih leluasa dan upaya pendokumentasian proses dapat direncanakan, sehingga kualitas bahan promosi biasanya lebih terkontrol. Selain itu, menggambar langsung di studio membuka kesempatan bagi pemesan untuk mengenal dan menikmati karya-karya yang terpajang di studio. Tak mustahil transaksi terhadap karya terpajang bisa terjadi.

Pilihan menggambar lewat foto di studio biasanya menghasilkan karya yang maksimal. Upaya pendokumentasian proses dan karya juga dapat dipersiapkan lebih apik dan berkualitas, sehingga dapat menjadi bahan materi promosi yang handal di media sosial jika benar-benar diupayakan.

Bukan hanya proses dan karya akhir yang dapt dijadikan bahan promosi, serah terima karya oleh Perupa kepada Pemesan, atau bisa juga dari pemesan ke penerima karya (jika karya pesanan dimaksudkan untuk hadiah) merupakan bahan promosi yang menarik di media sosial. Dokumentasi aktivitas ini dapat menjadi bukti pengesahan, bahwa karya itu benar adanya dan ada pemesannya. Nilai promotifnya bertambah jika aktivitas serah terima berlangsung dalam acara seremonial, disaksikan banyak orang dan mendapat liputan media. Dari sisi promosi, dokumentasi seremonial memiliki nilai berharga, terlebih jika penerima seorang tokoh yang dikenal dan dihargai, sehingga dapat mencerminkan capaian reputasi.

\section{b. Pesanan Lukisan Umum}

Dari sekian banyak lukisan yang pernah diciptakan, ada jenis-jenis lukisan yang sangat populer dan diminati banyak orang yaitu pemandangan (sawah, gunung, laut), bunga, buah-buahan, alam benda, penari bali, kuda, harimau, ikan koki, ikan koi, burung, pasar, pedesaan, perkampungan nelayan, kaligrafi, dll. Lukisan sejenis ini lazim dipesan oleh toko dan kios penjual lukisan, galeri penjualan online, ketika persediaan habis..

Namun, beberapa tahun belakang ini Perupa Informan mulai membatasi pesanan Lukisan Umum dari pasar seni serupa itu, karena penawaran yang terlalu murah. Mereka lebih suka melayani permintaan dari konsumen langsung, Di lain pihak, tak sedikit konsumen yang tidak puas dengan ketersediaan lukisan umum di pasar-pasar seni, karena beberapa alasan, biasanya terkait ukuran, dominasi warna tertentu, pose tertentu atau karena ingin dilukis oleh perupa tertentu untuk tujuan koleksi dan investasi.

Jenis Karya seperti ini sangat memungkinkan upaya pendokumentasian proses dan karya akhir yang berkualitas, 
sehingga dapat menjadi bahan materi pasar di media sosial perlu dirintis dan promosi yang handal di media sosial jika diupayakan.

benar-benar diupayakan.

\section{c. Pesanan Lukisan Khusus}

\section{Hewan Peliharaan}

Pemilik hewan peliharaan biasanya Pesanan lukisan khusus umumnya karena obyek lukisan bersifat khusus dan tidak tersedia di galeri dan pasar seni. Selama pengumpulan data di lapangan pengalaman mendapat pesanan khusus ini banyak ragamnya seperti, Pemandangan Kampung Halaman, Hewan Peliharaan, Kendaraan Kesayangan, Bangunan, Tema Tertentu dalam jumlah banyak, Tokoh Kharismatik, Tokoh Mitos

\section{Pemandangan Kampung Halaman}

Banyak tersedia lukisan bertema pemandangan yang indah, tapi mungkin tidak terkait dengan pengalaman emosional seseorang. Bagi para perantau lukisaan pemandangan kampung halaman mungkin bukan sekadar penghias ruangan tapi sekaligus pembangkit kenangan dan pengobat kerinduan. Saat penelitian berlangsung ternyata ada pemesan lukisan pemandangan tentang kampung halaman tempat dimana pemesan dilahirkan dan dibesarkan. Permintaan datang dari pemesan dan bukan inisiatif dari perupa. Keinginan terhadap lukisan pemandangan kampung halaman tak mustahil diminati banyak perantau, Promosi gencar terhadap target memiliki hubungan emosional dengan hewan kesayangannya. Mengabadikan dalam bentuk lukisan adalah pilihan menarik, karena umur hewan peliharaan biasanya pendek. Selain menjadi dekorasi ruangan, lukisan dapat menjadi kenangan manis. Target pasar konsumen sangat terbuka luas, namun pesanan lukisan seperti masih ini terbilang langka. Keinginan terhadap lukisan hewan peliharaan mungkin diminati banyak pencinta binatang, Promosi gencar terhadap target pasar di media sosial perlu dirintis dan diupayakan.

\section{Kendaraan Kesayangan}

Ternyata bukan benda hidup saja seperti hewan peliharaan yang dipesan menjadi lukisan, para pemilik kendaraan kesayangan pun rupanya ada yang meminta dibuatkan lukisan kendaraannya. Seperti halnya hewan peliharaan permintaan jenis lukisan seperti ini pun masih sangat langka.tapi ada. Keinginan memiliki lukisan kendaraan kesayangan perlu dibangkitkan. Promosi gencar terhadap target pasar di media sosial perlu dirintis dan diupayakan. 
Bangunan

Pesanan khusus lainnya adalah obyek bangunan. Yang populer adalah pesanan bangunan heritage dan permintaan developer untuk promosi perumahan Sedangkan pemilik bangunan (hotel, bank, cafetaria), pemilik rumah tinggal jarang memesan lukisan bangunan miliknya, namun selama penelitian berlangsung permintaan serupa itu pernah ada. Kesadaran untuk berkebutuhan lukisan sejenis ini mungkin belum tumbuh. Promosi gencar terhadap target pasar di media sosial perlu dirintis dan diupayakan.

\section{Tema Tertentu dalam jumlah banyak}

Gedung perkantoran baru, Hotel dan restoran baru, Cafetaria yang kian banyak bermunculan seiring perkembangan di bidang pariwisata dan kuliner membutuhkan banyak lukisan untuk mendekorasi ruangan. Konsumen yang membutuhkan lukisan dalam jumlah banyak seperti ini biasanya menginginkan tema tertentu.

Tema lukisan biasanya disesuaikan kondisi tempat dan konsep positioning yang mereka usung. Jika tema yang diinginkan bersifat umum seperti lukisan bunga, burung, pemandangan, mereka sebenarnya memiliki pilihan untuk membeli lukisan jadi di galeri/ pasar seni. Namun jika tema yang diinginkan sangat spesifik (tema, gaya, media, ukuran) biasanya lebih menyukai melakukan pemesanan daripada memborong di galeri/pasar atau pasar seni.

Developer, pemilik bangunan yang sedang membangun gedung merupkan sasaran potensial untuk promosi. Jika memungkinkan menjalin hubungan secara personal promosi dapat dilakukan secara tatap muka. Sekurangnya ketersediaan media berupa proposal dapat dipersiapkan berikut lampiran karya yang pernah dihasilkan Jika perupa memiliki dokumentasi yang handal terkait dengan karya-karya yang pernah dihasilkan, hal tersebut sangat bermanfaat

\section{Tokoh Kharismatik}

Tokoh kharismatik lazim menjadi obyek pesanan pada para perupa. Kekaguman pada sang tokoh, biasanya menjadi motif utama, namun mungkin juga didasari motif lainnya. Tokoh Soekarno, sebagai misal. Lukisan sosok Soekarno sepertinya tidak pernah kehilangan pasar. Keluarga terkait, pengagum dan anggota partai tertentu merupakan konsumen potensial untuk lukisan tersebut. Membangun hubungan baik dengan pihakpihak terkait merupakan langkah masuk akal untuk membuka pintu promosi di saat yang tepat.

Adakalanya permintaan terkait dengan tokoh adalah berupa adegan tertentu bersama tokoh. Misalnya sang pemesan sedang sedang bersalaman dengan Presiden RI. Walaupun pemesan memiliki foto asli 
sebagai dokumen, salinan dalam bentuk lukisan dapat dapat lebih menarik. Lukisan dapat meniadakan hal-hal yang tak perlu, seperti kehadiran orang-orang di sekitar dan di latar belakang dan ukuran dapat dipesan sesuai keinginan. Auranya menjadi sangat berbeda. Para pejabat, eksekutif korporat adalah sasaran potensial untuk jenis lukisan seperti ini.

\section{Tokoh Mitos}

Tokoh mitos menjadi salah satu jenis pilihan lukisan khusus lainnya. Nyi Roro Kidul, misalnya Kisah Nyi Roro Kidul memiliki banyak versi. Terlepas dari kisah mana yang lebih dipercaya kedudukan Nyi Roro Kidul sebagai Ratu Lelembut Laut Pantai Selatan menjadi motif populer dalam cerita rakyat dan mitologi. Sebagai mitos, kisahnya melekat dalam beragam artefak budaya; seni musik, seni teater, seni sastra dan seni rupa. Dalam seni rupa tak terbilang jumlah lukisan yang pernah dihasilkan para seniman dengan berbagai ekspresinya.

Kalangan yang percaya merupakan konsumen potensial untuk memiliki lukisan jenis ini. Bagi mereka, memiliki lukisan Nyi Roro Kidul seperti beroleh kesempatan memuliakan Tokoh Penguasa Laut Selatan. Mereka berharap dengan memiliki Lukisan Nyi Roro Kidul mereka dapat terjaga dari mara bahaya, mendapat keberkahan dalam berbagai bentuk; kekuasaan, jabatan, keberlangsungan usaha dsb. Begitu bersemangatnya kelompok jenis ini, bagi yang mampu, mereka tak segan membeli lukisan dengan harga yang mahal, memesan salinan ulang dari sebuah lukisan yang telah terjual, bahkan memesan sosok dirinya menjadi sosok Nyi Roro Kidul dalam lukisan. Berdasarkan pengalaman perupa informan, bantuan dari paranormal untuk melegimitasi karya yang dihasilkan sangat bermanfaat untuk melicinkan upaya promosi jenis lukisan ini.

\section{d. Desain dan Illustrasi,}

Mendapatkan pesanan illustrasi menjadi salah satu pekerjaan lain yang lazim diperoleh perupa informan. Kebutuhannya bisa untuk beragam keperluan. Illustrasi buku, illustrasi artikel di medi massa cetak, illustrasi media promosi dll. Bahkan tak jarang permintaan illustrasi sekaligus dengan desain secara keseluruhan.

Produk karya untuk illustrasi biasanya diproduksi secara massal. Dari sisi promosi, media yang diproduksi menjadi media promosi tersendiri. Dengan demikian sekalipun harga penawaran bisa tidak memenuhi harapan, tawaran seperti ini layak untuk dipertimbangkan. Jika dikhawatirkan pembaca diperkirakan mungkin tidak menyadari bahwa illustrasi tersebut adalah karya perupa yang bersangkutan, sejak dalam proses dan hasilnya sebaiknya 
didokumentasikan dengan baik. Sehingga dapat menjadi bahan promosi menarik untuk dibagikan di media sosial di saat-saat dibutuhkan Materi seperti ini sangat memungkinkan dipromosikan secara berulang pada saat-saat yang tepat.

\section{Pesanan Karya Bersama}

Berbeda dengan Pesanan Karya Mandiri yang dikerjakan oleh perupa informan secara individual Pesanan Karya Bersama melibatkan pihak lain. Pesanan karya yang dilakukan bersama biasanya karena berskala besar, terlalu rumit, menyangkut-hal-hal di luar keahlian perupa yang mendapatkan pesanan atau karena ketersediaan waktu yang terbatas. Pihak lain yang dilibatkan bisa berperan sebagai Artisan atau Bekerja Bersama Tim.

\section{a. Pesanan Karya Bersama Artisan}

Perupa yang sudah memiliki nama besar kerapkali tidak bisa menghindari bantuan seorang atau lebih Artisan. Kegiatan Artisan membantu pekerjaan seorang seniman, bisa sebagian kecil, bisa sebagian besar. Namun eksekusi akhir dan yang menandatangani karya tetap seniman utama yang mendapat pesanan. Memberi pekerjaan pada Artisan dan menjadi Artisan, merupakan bagian lain dari kegiatan perupa informan.
Sebagai pemberi kerja pada Artisan, perupa bersangkutan yang berhubungan langsung dengan pemesan. Ada baiknya sejak awal penggunaan artisan ini dibicarakan sejak awal dengan pemesan. Umumnya keterbukaan seperti ini tidak bermasalah, bahkan lebih ideal dalam sertifikat karya (perupa bereputasi biasanya menyediakan sertifikat keaslian karya) nama Artisan dimuatkan. Promosi bagi pemberi kerja tak ubahnya seperti promosi karya pesanan mandiri. Dokumentasi proses dan karya akhir yang handal sangat memberi dukungan.

Sedangkan jika posisi perupa sebagai Artisan, pilihannya berbeda. Menjadi Artisan bagi sebagian perupa sering menjadi masalah kontroversial. Tidak semua perupa bersedia, tapi banyak juga yang tidak menolak. Beberapa perupa bahkan bangga dipercaya menjadi Artisan seniman besar. Artinya, kemampuannya diakui. Karena tidak semua yang mengaku pelukis bisa jadi Artisan perupa yang sudah dikenal. Namun, tentunya etika yang disepakati sebagai Artisan harus dijaga, karena ketika karya diselesaikan, yang bersangkutan tidak berhak mengaku karya tersebut sebagai karyanya.

Untuk karya bersama Artisan seperti ini, upaya promosi sama halnya dengan jenis pesanan lain. Namun hak dan kendali promosi hanya berlaku untuk Perupa Utama. Terkait dengan karya tersebut Artisan tidak berhak membuat promosi tersendiri. Namun, 
frekuensi kebersamaan dengan Perupa khusus, dan hadirnya budaya swaphoto bereputasi menjadi promosi tersendiri. (selfie) permintaan lukisan mural meningkat Kebersamaannya dengan perupa pemberi di berbagai kota tujuan wisata. Lukisan kerja tentu dimungkinkan menjadi bahan dengan cat, sablon dan airbrush untuk iklan promosi bagi dirinya selama tidak terkait media luar ruang seperti spanduk, balighoo dengan karya yang dikerjakan bersama. dan billboard memang sudah menghilang Dengan begitu keberadaan seorang Artisan digantikan digital printing. Namun tingkat bisa ikut cemerlang karena hubungan.

\section{b. Pesanan Karya Bersama Tim}

Berkarya bersama Tim berbeda dengan berkarya bersama Artisan,. Hasil akhir merupakan karya bersama, bukan karya tunggal penerima pesanan. Pemesan juga memang sejak awal tidak menuntut karya siapa .Walaupun sangat dimungkinkan ada koordinator perannya semata-mata lebih berfungsi manajerial

Selama proses penelitian berlangsung beberapa pekerjaan bersama Tim yang dikerjakan tim perupa informan adalah Lukisan Mural Gubernur dan Wakil Gubernur Jabar beserta aktivitasnya di halaman kantor PU Jalan Asia Afrika Km0, Mural di tempat wisata dan Mural Sketsa di Selasar Museum Gedung Sate.

Walaupun teknologi printing sudah demikian maju dan mampu mencetak image dalam ukuran sangat besar (5m x 50m) permintaan melukis dengan ukuran sangat besar di dinding kosong (mural) ternyata tidak berkurang. Bahkan dengan berkembangnya usaha di bidang kuliner, menjamurnya kafé, rumah makan bertema keawetan hasil cetak digital printing sangat terbatas. Terlebih jika dipasang di luar ruangan. catnya cepat memudar dalam jangka waktu hitungan bulan. Sedangkan lukisan di dinding seperti mural cat nya lebih awet, bisa tahunan.

Ukuran karya yang besar, jumlah perupa yang terlibat serta, dan hasil karya yang menjadi milik publik merupakan bahan untuk promosi yang menarik sejak mulai awal proses berkarya bahkan hingga pasca karya diselesaikan. Dokumentasi yang handal sangat terbuka untuk dipersiapkan. Dokumentasi yang handal akan memberi manfaat positif saat promosi di media sosial dilaksanakan.

\section{SIMPULAN}

Jenis-jenis karya yang dihasilkan oleh perupa informan terkait bidang seni rupa ternyata sangat beragam. Secara garis besar jenis karya yang beragam dikategorikan menjadi 2 jenis yaitu Karya Independen dan Karya Pesanan.

Karya Independen adalah karya yang merupakan ekspresi bebas berdasarkan pada 
keinginan pribadi perupa sendiri. Karya seperti ini dipastikan bukan pesanan pihak lain. Karya independen dapat dibedakan sebagai berikut: Karya pribadi, Karya Kompetisi, Karya Insidental, Karya Uji Coba, Karya Berdasarkan Tantangan dan Karya dalam Event

Karya Pesanan adalah karya yang dibuat berdasarkan permintaan konsumen Permintaan pesanan seperti seringkali bearasal dari orang yang dikenal, pelanggan, galeri, kolektor atau tidak tertutup kemungkinan dari orang yang asing namun mendapat rekomendasi dari seseorang

Ragam pesanan secara garis besar dapat dibagi 2 menjadi Pesanan Karya Mandiri dan Pesanan Karya Bersama

Pesanan Karya Mandiri dapat berupa Pesanan Lukisan Wajah, Pesanan Lukisan Umum, Pesanan Lukisan Khusus (Pemandangan Kampung Halaman, Hewan Peliharaan, Kendaraan Kesayangan, Bangunan, Tema Tertentu dalam jumlah banyak, Tokoh Kharismatik, Tokoh Mitos), Desain dan Illustrasi, Sedangkan Pesanan Karya Bersama dapat berupa Pesanan Karya Bersama Artisan, Pesanan Karya Bersama Tim

Walaupun masing-masing kategori membutuhkan kekhususan, materi bahan promosi dapat berupa dokumentasi proses dan dan dokumentasi karya akhir. Sebagian besar jenis karya memungkinkan upaya pendokumentasian dengan persiapan terlebih dahulu, sehingga dapat menghasilkan bahan promosi yang maksimal.

\section{DAFTAR PUSTAKA}

Creswell,. John W, 1998. Qualitative Inquiry and Research Design: Choosing Among Five Traditions, USA, Sage Publications Inc.

Kotler, Philip. 2000. Manajemen Pemasaran Edisi Milenium Jilid 1. Jakarta: Penerbit Erlangga.

Kotler, Philip. 2000. Manajemen Pemasaran Edisi Milenium Jilid 2. Jakarta: Penerbit Erlangga.

Littlejohn, Stephen W, 2005, Theories of Communication, Eighteen Edition, Belmont California: Wadsworth Publishing Company

Maria, Mia, Asep Topa, Dila Martina Ayu, 2014, Rencana Pengembangan Seni Rupa 2015-2019, Kementerian Pariwisata dan Ekonomi Kreatif RI,

Moleong, Lexy, 2007, Metodologi Penelitian Kualitatif, Bandung: PT Remaja Rosdakarya

West, Richard, Lynn H. Turner, 2008a, Pengantar Teori Komunikasi Analisis dan Aplikasi Edisi 3 Buku 1, Terjemahan Maria Natalia Damayanti Maer, Jakarta: Penerbit Salemba Humanika

West, Richard, Lynn H. Turner, 2008b, Pengantar Teori Komunikasi Analisis dan Aplikasi Edisi 3 Buku 2, Terjemahan Maria Natalia Damayanti Maer, Jakarta: Penerbit Salemba Humanika

Yin, Robert K. 1996, Studi Kasus Desain dan Metode, Jakarta: Raja Grafindo, 